\title{
The economy of attention in the age of mental capitalism ${ }^{\star}$
}

\author{
D. A. Kolesnikova
}

Bauhaus University Weimar,

26, Leonhard-Frank Straße, Weimar, 99425, Germany

For citation: Kolesnikova D. A. The economy of attention in the age of mental capitalism. Vestnik of Saint Petersburg University. Philosophy and Conflict Studies, 2019, vol. 35, issue 4, pp. 563-568. https://doi.org/10.21638/spbu17.2019.403

The paper explores the contemporary implementation of attention as a scarce resource, which the economy, politics, and media culture must manage, distribute, and speculate. The purpose is to analyse the commodification of human capacities of attention within the paradigm of media philosophy. Conceptualisations such as "mental capitalism," competition for "eyes," and "clickthroughs" were identified as particular instantiations of forms in social media, photography, and art - from Instagram and Facebook to graffiti. I promote the view that visuality is an essential, contradictory, and inherent feature of the mental capitalism and its economy of self-esteem. In order to reframe a polemical account of the contemporary tendency of global capitalist technoculture, I briefly characterize the critical perspectives on the attention economy by Jonathan Beller and Bernard Stiegler. Finally, I emphasize the role of ecological and ethical responsibility in interpersonal relations and structures of social practices in the situation of "fight for attention." The tasks of visual ecology in the age of mental capitalism are an elaboration of productive criteria of visual pollution, organization of the new forms of community strategies and policies, through attentive reflection of images and media milieu in which they develop, which are able to reconcile the contradictions between the technical and the natural.

Keywords: economy of attention, mental capitalism, self-esteem, media philosophy, visual ecology, media consumption, social media, politics of media.

Attention is one of the characteristics of human existence, which plays a fundamental role in the processes of understanding and communication. The question of administration and distribution of attention has been significant since antiquity. Attention is the engine of the two booming areas of the present - media culture and science. Nowadays attention receives new roles and values as a deficient resource and medium, analysed within the law of information first formulated in 1971 by Herbert Simon: "... a wealth of information creates a poverty of attention" [1, p.40]. If an economy is the means and rationale through which a given society commodifies and exchanges scarce resources, then the "attention economy," following Marazzi [2], defines human attention as a scarce but quantifiable commodity. According to Goldhaber [3], the economy of attention is the techno-cultural milieu in which contemporary Western societies operate and in which the "web-native" generation lives.

In the last twenty years there has been an extensive review of issues relating to the economy of attention, which is documented in a constant variety of publications. The debates on the current notion of attention were fruitfully summarized by Jörg Bernardy

* The article is written with the support from RFFR, project "Politics of media" (18-011-00414 A).

(c) Санкт-Петербургский государственный университет, 2019 
[4] as follows: In general there are four main fields in which attention plays a more or less important role and where it is the object of theoretical works: (1) cognitive sciences and psychology, (2) cultural studies and literature (Frank Kermode, Aleida and Jan Assmann), the field of (3) economics which is the most problematic field because it is not only rooted in economics, but seems to be rather an interdisciplinary approach of psychological, sociological, philosophical and economic thinking within the paradigm of media culture and communication (Herbert Simon, Georg Franck, Michael Goldhaber, David N.Lanham). Finally, attention appears in the discourse of (4) phenomenology which is, regarding the phenomenon of attention, represented primarily by Edmund Husserl, Paul Valéry and Bernhard Waldenfels in philosophy.

A sense of the implications on the economy of attention as a theory of mental capitalisms is most eloquently offered by Georg Franck. Georg Franck is a professor of computer-aided planning and architecture at the Vienna University of Technology. In 1998 he published a book entitled "The Economy of Attention" (in German: "Ökonomie der Aufmerksamkeit") [5], in which he explains the cohesion of society through the exchange and administration of attention. He bases his theory on the constellation of "mental capitalism" founded upon the "socialisation of prominence" and "decline of material wealth." Suppliers technically reproduce media content while the audience "pay" through live attention to each copy: "It is one of the most significant economic changes of this century where the service of rendering attention has overtaken all other production factors in economic importance" [6]. The economy of attention exists alongside the economy of money and competes with it. A medium's financial success in turn depends on its ability to be used as marketable advertising space. Frank's statements on mental capitalism are now becoming even more relevant, which proves the phenomena of "The Digital Advertising Duopoly" - Facebook and Google control about 75\% of attention, monetized through online advertising. In 2017 US advertisers spent $\$ 35 \mathrm{~B}$ with Google and $\$ 17.4 \mathrm{~B}$ with Facebook according to eMarketer. In 2018 those totals are forecasted to be $\$ 39.9 \mathrm{~B}$ and $\$ 21 \mathrm{~B}$ for Google and Facebook respectively [7]. Circulation size and TV ratings, social media metrics, built on amounts of "likes," "clicks" and "shares," volatility of cryptocurrency - are measures of the attention drawn by media. The optimal rate of mental capital formation has greater weight than the rate of real capital investment. It is also more important than physical resources, regardless of their excellent endowment. The different types of capital of attention are: prestige, reputation, prominence and fame. "Attention from other people is the most irresistible of drugs. Receiving attention surpasses any other kind of income. This is why glory overshadows power and why wealth is exceeded by prominence" [6].

At the core of Franck's philosophical foundation is his orientation to Heidegger's concept of "Dasein," augmented by an ethical perspective with the philosopher Emmanuel Levinas. His theory revolves around the desire and state of the individual to play a role in the consciousness of others. "Receiving alert attentiveness means becoming part of another world. No attentive being has direct access to the world of another being's attention. By receiving another being's attention, however, the receiving one becomes represented in that other being's world. And it is one's representation in the other being's consciousness which makes the desire to be noticed so irresistible" [6].

Attention cannot be accumulated in the same ways as money but, Franck argues, it can be calculated through "esteem." The economy of self-esteem is based on the desire for attention and the concern for self-worth. In this context, knowledge and education 
are becoming increasingly important. The aim of education, for Franck, is the acquisition and application of knowledge; it is a form of capitalized attention that constitutes a "mental capitalism." For the embedding of an individual into society, Franck employed numerous ideas and thoughts from sociology and philosophy, such as Mead's concept of the generalized other [8]. "Attention is the essence of being conscious in the sense of both a self-certain existence and an alert presence of mind. Attention is the medium in which everything must be represented that is to become real for us as experiencing creatures. Each attentive creature is the centre of its own individual world. This world exists as many times as there are conscious beings" [6].

The relevant time diagnosis is that the economy of attention has become a principle of modern self-esteem. However, attention, embodied as a cognitive capacity, is expressed not only consciously, but also sub-consciously in the various ways in which we comprehend and interact with the world. The endless opportunity for self-promotion and self-reflection on social media (especially on YouTube and Instagram) have resulted in a fascination with all things visual, from "high" to "low," and from "freaky" to popular. Roger Munier's pamphlet "Against Images," puts it in the following manner: "Where with language we have a discourse on the world, with human beings facing the world in order to name it, photography substitutes the simple appearance of things; it is a discourse of the world... Images now allow for the paradox that the world states itself before human language" $[9, \mathrm{p} .32]$. The mass dissemination of visual culture gave rise to what researchers refer to as our era "the civilization of the image" [10], and the situation in culture - "an iconic turn" [11; 12], which is characterized by a shift in the ontological perspective to the analysis of visual images. What we see, and what we do not want to pay attention to, but look at - becomes our inner self, an image of reality. Images are what they apply to us. "There is nothing more real than images which we remember. Nothing exerts greater power over us than that which forces us to take attentive note. Everything to which we inadvertently pay attention, inadvertently exerts some effect on us" [6].

Thanks to smartphones, millions of people around the globe are turning into prolific photographers. Within an hour more images could be taken, than in an entire decade in the past. According to estimates from InfoTrends, people will take 2 trillion digital photos in 2018 [13]. Since the meteoric rise of "Instagram" as the number one photo social platform [14], where individuals use self-portraits, photographs and images to express themselves rather than written self-descriptions, self-esteem practices in the internet become more and more determined by the logic of visual media.

Johnathan Crary raises the question of the political-economy of visuality, he notes that "photography and money become homologous forms of social power in the nineteenth century. They are equally totalizing systems for binding and unifying all subjects within a single global network of valuation and desire" [15, p. 112].

The value of images is created by the gaze that is directed towards them. Our gazes accrete on the image and intensify its power. Image as a good is only valuable when it can attract "eyeballs" [16, p. 75]. But images not only follow the modes of visual economy, they consist of an immanent economy in its surface: anyone who produces an image needs to balance out carefully its pictorial means to keep the attention. For instance, graffiti could be one of the many visual signs, quickly sprayed on the wall in any megapolis. A passerby, walking along, may not pay attention to such writing on a blank billboard: "The joy of not being sold anything" - the graffiti made by artist Banksy in 2008. Banksy does not 
appear as a person in public, but uses the public space as a gallery of his works. His works are highly traded on the market, for instance "Keep it spotless" (Damien Hirst persiflage) was sold at Sotheby's for 1.7 million dollars. His street art works are unique, they are circulated by photographic and mass media reproduction. These in turn, promoted by the prominence of the artist's name, contribute to increasing the artist's perception or visibility perhaps because the artist remains invisible. Occasionally, images — or at least their originals - even remove themselves from visibility to draw attention. Banksy's works inevitably remain: they exist until the city cleaner removes them from the wall and then they become implicated into the cycle of the pictorial economy as photographic reproductions.

The Visual diversity and its media's supply keeps growing. A major part of socially perceived media reality is highly synthetic, as it is especially produced for use by a wide range of informal workers, content providers, gamers, consumers, prosumers or audiences in the fight for attention. As spectators begin to value their attention, corporations struggle to get more of what they previously received for nothing.

Redefinition and institutional reforming of cultural production, art, labour, leisure and education leads to a critical account of the attention of economy rhetoric. Jonathan Beller develops a materialist critique of cognitive capitalism and its economy built on visuality, spectacle and the mobilisation of the "sensuous labour" of the worker-consumer. "We confront the logistics of the image wherever we turn - imaginal functions are today overlaped in perception itself. Not only do the denizens of capital labour to maintain themselves as image, we labour in the image. The image, which pervades all is the mise-en-scène of the new work" [17, p.41]. Beller states that critical theory might do well to pay attention to how those, who are excluded from the immaterial virtual citizenry of the digital future, try to make something of and with the digital media designed not for their benefit [18].

Systems for attracting and managing people's attention will continue to improve rapidly: new formats (eye-catching techniques), the use of machine learning (Cambridge Analytica) and centralization (Google, Facebook) will lead to qualitative changes in the mediascape, where people will need to deploy active protection against large-scale and aggressive influence on their limited attention. Bernard Stiegler notes that today, "attentional" techniques and technology tend to be replaced by industrially mass produced "attentional technologies" that are designed to generate one particular kind of attention consumption. In "Taking Care of Youth and the Generations," Stiegler announces a battle for criticality that must be fought, or rather re-commenced against the mainstream adoption of digital technology's potential [19]. This is precisely the point and the possibility of paying attention to attention: to reanimate the potential for a less poisonous adoption of the widely recognised potential of digital audio-visual culture in order to re-form (remediate) culture, sociality, economy and ecology today [20].

The less we monitor the impact of the visual environment on us, the deeper and inescapable it becomes. And, on the contrary, the actualization of the perception's experience through media gives us a chance to avoid the extreme forms of manifestation of visual pollution. The latter opens up the problematic research field to a new discipline - visual ecology, which has found a place within the framework of media philosophy.

The project of "visual ecology" results in a research field affecting the issues of attention economy: the problem of mass deformation of regimes and speed of perception, transformation of perception by means of media, problems of visual pollution and visual violence, research of interpersonal relations and structures of social practices in the con- 
texts of forming ecological and ethical responsibility. In the context of visual ecology, images and various visual contents are considered as comprehensive medial surfaces, the potential of which is revealed in social, cultural, and everyday practices. Tasks of visual ecology are the elaboration of a productive systematic view on changing the visual environment and organization of new forms of community strategies and policies that reflect the notion of visual media as form of attention capture [21].

\section{References}

1. Simon, H. (1971), "Designing Organizations for an Information-Rich World", Computers, Communications, and the Public Interest, Johns Hopkins University Press, Baltimore.

2. Marazzi, C. (2008), Capitalism and Language: From the New Economy to the War Economy, trans. by Conti, G., Semiotext(e), Los Angeles.

3. Goldhaber, M. (1997), "The Attention Economy and the Net", First Monday, no. 2 (4), available at: https://firstmonday.org/article/view/519/440 (Accessed: 20.09.2019).

4. Bernardy, J. (2011) "Attention as bounded resource and medium in cultural memory: A phenomenological or economic approach?”, Empedocles, vol. 2 (2), pp. 241-254.

5. Franck, G. (1998), Ökonomie der Aufmerksamkeit. Ein Entwurf, Carl Hanser \& Co, München.

6. Franck, G. (1999), "The Economy of Attention", Telepolis, no. 7, available at: https://www.heise.de/tp/ features/The-Economy-of-Attention-3444929.html (accessed: 24.09.2018).

7. Ingram, M. (2018), How Google and Facebook Have Taken Over the Digital Ad Industry, available at: http://fortune.com/2017/01/04/google-facebook-ad-industry/ (accessed: 24.09.2018).

8. Mead, G. (1934), Mind, Self, and Society from the Standpoint of a Social Behaviorist, University of Chicago Press, Chicago.

9. Ruiz, R. (1995), Poetics of Cinema, trans. by Brian Holmes, Editions Dis Voir, Paris.

10. Virilio, P. (1994), The Vision Machine, trans. by Julie Rose, Indiana University Press, Bloomington.

11. Boehm, G. (1994), "Was ist ein Bild", Widerkehr der Bilder, W. Fink, München, pp. 11-38.

12. Mitchell, W.J.T. (1994), "The Pictorial Turn", Picture Theory. Essays on Verbal and Visual Representation, The University of Chicago Press, Chicago and London, pp. 11-34.

13. Finsterbusch, S., Heeg, T. (2018), Zwei Billionen Bilder, available at: http://www.faz.net/aktuell/ wirtschaft/mehr-wirtschaft/fotorevolution-2-0-wie-fotografie-immer-digitaler-wird-15800518.html (accessed: 24.09.2018).

14. Desreumaux, G. (2018), The Complete History of Instagram, available at: https://wersm.com/thecomplete-history-of-instagram/ (accessed: 24.09.2018)

15. Crary, J. (1999), Suspensions of Perception: Attention, Spectacle, and Modern Culture. MIT Press, Cambridge, MA.

16. Fairchild, Ch. (2007), "Building the Authentic Celebrity: The 'Idol' Phenomenon in the Attention Economy”, Popular Music \& Society, no. 30 (3), pp. 355-375.

17. Beller, J. (2006), The Cinematic Mode of Production: Attention Economy and the Society of the Spectacle, Dartmouth College Press and University Press of New England.

18. Bauwens, M. (2018), Towards a Critique of the Attention Economy: a special issue of 'Culture Machine', available at: https://blog.p2pfoundation.net/towards-a-critique-of-the-attention-economy/2012/07/28 (accessed: 24.09.2018).

19. Stiegler, B. (2010), Taking Care of Youth and the Generations, trans. by Barker, S., Stanford University Press, Stanford.

20. Crogan, P. and Kinsley, S. (2012), "Paying attention: towards a critique of the attention economy", Culture Machine, vol. 13, pp. 1-29.

21. Kolesnikova, D. A., Savchuk, V. V. (2015), "Visual Ecology As a Discipline”, Voprosy Filosofii, vol. 10, St. Petersburg, Russia, pp. 41-50.

Received: October 22, 2018

Accepted: June 13, 2019

Author's information:

Daria A. Kolesnikova — PhD in Philosophy, MA; daria.ko@gmail.com 


\section{Экономика внимания в эпоху ментального капитализма}

\section{Д. А. Колесникова}

Баухаус университет Веймара,

Германия, 99425, Веймар, Леонард-Франк-штрассе, 26

Для цитирования: Kolesnikova D. A. The economy of attention in the age of mental capitalism // Вестник Санкт-Петербургского университета. Философия и конфликтология. 2019. Т. 35. Вып. 4. С. 563-568. https://doi.org/10.21638/spbu17.2019.403

В статье рассматривается современный подход к пониманию внимания как ограниченного ресурса, который является объектом регулирования и спекуляции в цифровой экономике, политике и медиакультуре. Целью статьи является анализ феномена коммодификации потенциала человеческого внимания в рамках парадигмы медиафилософии. Понятия «экономика внимания», «ментальный капитализм», «борьба за «взгляды» и «клики» рассматриваются в различных медиаконтекстах — от Instagram и Facebook до граффити и фотографии. Выдвигается мнение о том, что визуализация является существенной и неотъемлемой чертой ментального капитализма и его «экономики самооценки». Описываются критические подходы к вопросам экономики внимания на основе работ Джонатана Беллера и Бернара Стиглера. Подчеркивается роль экологической и этической ответственности в межличностных отношениях и структурах социальных практик в ситуации «борьбы за внимание». В заключение приводится краткое описание проекта визуальной экологии как новой формы взаимодействия между окружающей средой, социумом и субъективностью, работающей с новыми практиками и этикой медиапотребления. Визуальная экология - область исследований воздействия визуальных образов на конституирование медиареальности. Вопросами визуальной экологии являются проблемы массовой деформации режимов и скорости восприятия, особенности формирования опыта восприятия посредством медиа, проблемы визуального загрязнения и визуального насилия. Задачей визуальной экологии является выработка продуктивного системного взгляда на изменения визуальной среды, интенсивности ее воздействия, критериев организации стратегий сборки новых форм сообществ и политик, в том числе через создание и рефлексию медиаобразов, способных примирить противоречия между техническим и природным.

Ключевые слова: экономика внимания, ментальный капитализм, медиафилософия, визуальная экология, медиапотребление, социальные медиа, политики медиа.

Статья поступила в редакцию 22 октября 2018 г.; рекомендована в печать 13 июня 2019 г.

Контактная информация:

Колесникова Дарья Алексеевна - канд. филос. наук, магистрант; daria.ko@gmail.com

* Статья написана при поддержке РФФИ, проект “Политики медиа” (18-011-00414 А). 